\title{
Developing Pedagogical Practices in Turkish Classrooms
}

\author{
Özge Cengizí ${ }^{1}$, Hamide Çakır ${ }^{2}$ \\ ${ }^{1}$ Department of Foreign Language Education, Istanbul Medeniyet University, Istanbul, Turkey \\ ${ }^{2}$ Department of Foreign Language Education, Niğde University, Niğde, Turkey \\ Email:ozge.cengiz@medeniyet.edu.tr,hamide.cakir@nigde.edu.tr
}

Received 13 February 2016; accepted 25 March 2016; published 28 March 2016

Copyright (C) 2016 by authors and Scientific Research Publishing Inc.

This work is licensed under the Creative Commons Attribution International License (CC BY). http://creativecommons.org/licenses/by/4.0/

(c) (i) Open Access

\section{Abstract}

According to socio-cultural theory (Vygotsky, 1978), learning and cognitive development take place through a social interaction between the learner and a more knowledgeable other, in classroom, a teacher. This study is an attempt to deal with teacher-student interaction within the framework of Bloom's Taxonomy of Cognitive Domain and to create some changes in teachers' pedagogical practices in Turkish classrooms. Bloom's Taxonomy was created to promote higher forms of thinking in education. In this study, first, teachers teaching Turkish to different grades at different schools were video-recorded in their classes with their students. After these observations, a teacher training course on Cognitive Domain and dialogicality was given to teachers in order to develop their awareness about their pedagogical practices and the cognitive level of the dialogue that takes place in the classrooms. Following the training, teachers were recorded in their classes in the same way again. Finally, after the discourse transcription, the cognitive levels of teachers' utterances were classified with regard to Cognitive Domain, and a comparison of the data recorded before and after the training was designed to determine whether the training course had positive effects on teachers. Since language has the power to shape our consciousness, even a small change in the language of schooling may result in students' participation, thus it can enhance their success. The results of this study indicated the benefit of training to carry out a more systematic and reflective pedagogical practice. The teachers who received training were able to produce utterances on the higher cognitive levels which also increased the cognitive levels of students' utterances and the dialogue in classrooms.

\section{Keywords}

Classroom Discourse, Teacher Talk, Bloom's Taxonomy of Cognitive Domain 


\section{Introduction}

Education is conducted fundamentally through social interaction, and this interaction takes place through classroom discourse. Teachers and learners mutually shape the academic discourse in the classroom (Hicks, 1995). Classroom activities are where students learn the language of schooling by repeated participation. Through this participation, students learn what to say, how to say, when to say, and when to stop in the academic setting (Hsiao, 2005).

Many studies have investigated the relationship between language and learning, among which Vygotsky's (1978) Zone of Proximal Development (ZPD) is one of the most influential. According to Wells (1999: p. 319), learning and teaching in the ZPD obviously depend on social interaction and this involves face-to-face interaction mediated by talk in classrooms; and he believes Vygotsky's claim, that talk plays a crucial part in children's learning in the ZPD and in the process of instruction (Zhang, 2008: p. 81). Mercer (2002) argues that for a teacher to teach and a learner to learn, both partners need to talk and create a shared framework of understanding. Talk is the principal tool for creating this framework. He thinks of shared understanding as an Intermental Development Zone (IDZ) in which educational activity takes place. The IDZ is constituted continually as the dialogue goes on, so enabling the teacher and learner to think together through the activity in which they are involved.

\subsection{Classroom Discourse}

Nunan (1993) views classroom discourse as the distinctive type of discourse that occurs in classrooms. At least 35 years ago, an important direction in applied linguistics and education research sought to understand the nature and implications of classroom discourse (Behnam \& Pouriran: 2009, p. 118). Classroom discourse is often different in form and function from language used in other situations because of the roles that students and teachers have in classrooms. Some of the features of classroom discourse include unequal power relationships, turn-taking, patterns of interaction, etc. Researchers focus on classroom discourse in order to find out what actually happens in the classroom (Carter \& Nunan, 2001). In classroom discourse studies, since developing students' higher-order thinking is important, teachers' instruction styles play an important role in the initiation of teacher talk.

\subsection{Teacher Talk}

Talk in classroom is crucial to learning. It is where answers to puzzling questions can be found, thoughtful argument and discussion make way for the understanding of new skills and different concepts and the meaning is negotiated (Smith, 2005: p. 86).

$\mathrm{Xu}$ (2010) claims that teachers should improve their talking and questioning behavior by providing an information gap between their students and themselves; that is, by asking them authentic questions (Faruji, 2011).

Walsh (2002) identifies a number of ways in which teachers can improve their talk to facilitate and optimize student contributions:

1) Examining more closely the link between pedagogic purpose and language use.

2) Devoting time for programs designed to provide the most beneficial ways of language use in the classroom.

3) Trying to understand more fully the qualitative aspects of language use in order to formulate a set of guidelines which constitute good practice in language use in the classroom.

4) Raising their awareness of their language use in the classroom by making audio or video-recordings of their lessons and analyzing the transcripts (Faruji, 2011: p. 1821).

If we think of talk as a vehicle for a process through which learners construct meaning, then questions and answers are vital. Questions are not only for the purpose of testing students' knowledge but also to enable them to develop and extend their thinking (Grugeon \& Hubbard, 2006: pp. 242-243). The concept of inter thinking is an important aspect of learning through dialogue. This inter thinking-the joint engagement with one another's ideas to think aloud together, solve problems or create mutual meaning - is an invaluable use of spoken language (Mercer, 2000).

From the research done on the topic so far, there has been a broad consensus on that the way teachers and students talk in the classroom is very important, and the dominant pattern of classroom discourse is monologic; that is, teachers dominate classroom interaction, and it should be replaced with more dialogic models in which 
students can talk as much as the teacher (Lefstein \& Snell, 2011).

\subsection{Bloom's Taxonomy of Cognitive Domain}

Bloom's Taxonomy is a framework for classifying statements of what students are expected to learn as a result of instruction. Bloom, for whom the levels of cognitive domain mean thinking skills, identified six levels in a hierarchical framework, from simple to more complex and from concrete to abstract; achievement of the next more complex skill or ability required achievement of the prior one (Krathwohl, 2002). The taxonomy is a model of classifying thinking hierarchically according to six levels of complexity; that is, each level is subsumed by the higher levels (Forehand, 2005). The taxonomy contains six levels. During the 1990's, Anderson, a former student of Bloom's, led a new assembly in order to update the taxonomy and the revision was published in 2001 including some changes in terminology which can be seen in Figure 1. The main difference between the two versions is that six major levels were changed from noun to verb forms. Another difference is that synthesis and evaluation levels in the original version have been reversed as evaluate and create. Therefore, the levels of the revised taxonomy are remember, understand, apply, analyze, evaluate, create. The first three levels, remember, understand and apply are regarded as lower-cognitive levels, while the other three levels are classified as highercognitive levels.

Each level consists of a verb that represents a cognitive process and a noun that describes the knowledge expected. For instance, as illustrated in Table 1, remember has two sub-objectives: recognizing and recalling, which means that remember represents the process, recognizing and recalling describe the knowledge expected (Anderson \& Krathwohl, 2001).

Bloom's Taxonomy built on earlier research by Vygotsky (1978), proposing that social interaction, and particularly the language during social interaction, is critical for children's cognitive development. In Table 2, there are some keywords and sample questions that exemplify each of Bloom's cognitive level.

No one level is better than another, they all serve a purpose depending on the situation but our ultimate goal must be to get to the higher levels. According to Fisher (2006: p. 228), as a good teacher, one might ask questions

Table 1. The cognitive processes: from lower to higher order thinking skills.

\begin{tabular}{|c|c|c|c|c|c|}
\hline \multicolumn{2}{|c|}{ Lower thinking skills } & & & \multicolumn{2}{|c|}{ Higher thinking skills } \\
\hline Remember & Understand & Apply & Analyze & Evaluate & Create \\
\hline $\begin{array}{l}\text { recognizing } \\
\text { recalling }\end{array}$ & $\begin{array}{l}\text { interpreting } \\
\text { exemplifying } \\
\text { classifying } \\
\text { summarizing } \\
\text { inferring } \\
\text { comparing } \\
\text { explaining }\end{array}$ & $\begin{array}{l}\text { executing } \\
\text { implementing }\end{array}$ & $\begin{array}{l}\text { differentiating } \\
\text { organizing } \\
\text { attributing }\end{array}$ & $\begin{array}{l}\text { checking } \\
\text { critiquing }\end{array}$ & $\begin{array}{c}\text { generating } \\
\text { planning } \\
\text { producing }\end{array}$ \\
\hline
\end{tabular}

(Adapted from Anderson \& Krathwohl, 2001: pp. 67-68).

Table 2. Keywords and sample questions for each cognitive level.

\begin{tabular}{|c|c|c|c|c|c|}
\hline Remember & Understand & Apply & Analyze & Evaluate & Create \\
\hline $\begin{array}{l}\text { Keywords: who, what, } \\
\text { when, which, define, } \\
\text { name, list }\end{array}$ & $\begin{array}{l}\text { Keywords: why, } \\
\text { rephrase, translate, } \\
\text { compare, contrast, } \\
\text { summarize }\end{array}$ & $\begin{array}{l}\text { Keywords: make use } \\
\text { of, organize, develop }\end{array}$ & $\begin{array}{l}\text { Keywords: analyze, } \\
\text { divide, classify, relate }\end{array}$ & $\begin{array}{l}\text { Keywords: criticize, } \\
\text { assess, justify, } \\
\text { opinion, judge }\end{array}$ & $\begin{array}{l}\text { Keywords: predict, } \\
\text { invent, make up, } \\
\text { propose, construct, } \\
\text { imagine }\end{array}$ \\
\hline $\begin{array}{l}\text { Questions: What } \\
\text { is ...? Where is ...? } \\
\text { When did ... happen? } \\
\text { How is...? }\end{array}$ & $\begin{array}{l}\text { Questions: } \\
\text { Why did ... happen? } \\
\text { How would you } \\
\text { summarize ...? } \\
\text { What is the main idea } \\
\text { of ...? } \\
\text { What is meant by ...? }\end{array}$ & $\begin{array}{l}\text { Questions: How } \\
\text { would you } \\
\text { organize ...? } \\
\text { What approach would } \\
\text { you use to ...? } \\
\text { How would you } \\
\text { solve ...? }\end{array}$ & $\begin{array}{l}\text { Questions: What are } \\
\text { the parts or features } \\
\text { of ...? } \\
\text { How is ... related } \\
\text { to ...? } \\
\text { How would you clas- } \\
\text { sify ...? }\end{array}$ & $\begin{array}{l}\text { Questions: What is } \\
\text { your opinion of ...? } \\
\text { How would you rate } \\
\text { the ...? } \\
\text { Why was it better } \\
\text { that ...? }\end{array}$ & $\begin{array}{l}\text { Questions: Can you } \\
\text { predict the outcome } \\
\text { if ...? } \\
\text { What changes would } \\
\text { you make to solve ...? }\end{array}$ \\
\hline
\end{tabular}

(Adapted from Bloom, 1956; Krathwohl, 2002). 


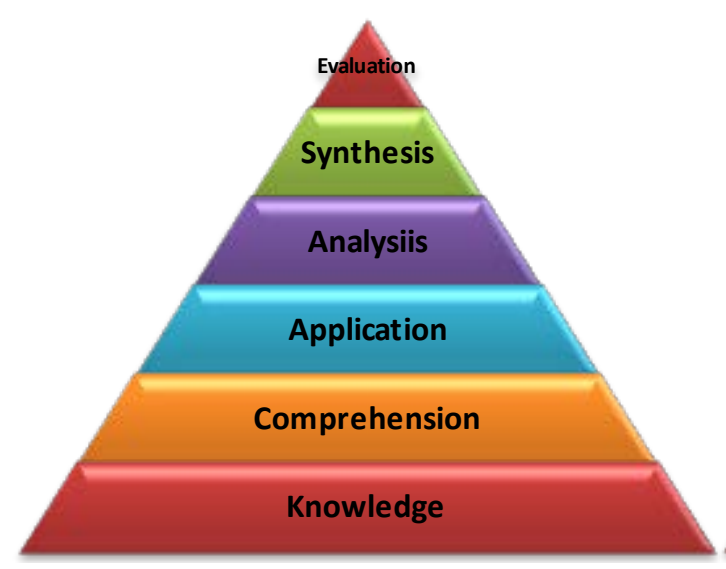

Old Version

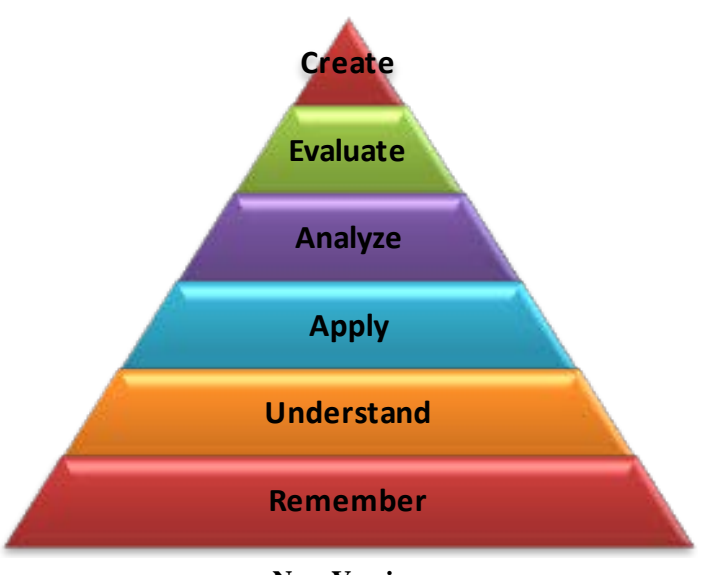

New Version

Figure 1. Bloom’s Taxonomy (Anderson \& Krathwohl, 2001).

that challenge students' thinking, and while telling a story, a teacher might ask the following typical questions:

- Remember: What happened in the story?

- Understand: Why did it happen that way?

- Apply: What would you have done?

- Analyze: Which part did you like best?

- Evaluate: What do you think of the story and why?

- Create: Can you think of a different ending?

If we want our students to talk to learn-as well as learn to talk then what they say probably matters more than what teachers say (Alexander, 2004: p. 19). There is a need to change pedagogic practices so that the dialogue that takes place in the classroom between teachers and students and between students themselves can become a powerful learning tool (Grugeon \& Hubbard, 2006: p. 239). Since one of the influential factors in creating classroom interactions is the type of questions which are asked by teachers, the present study sets out to investigate whether teachers' questions asked in the higher-cognitive levels of Bloom's Taxonomy create interaction; that is, make classrooms more dialogical and raise the cognitive level of the classroom discourse. In order to achieve this, a training program on Bloom's Taxonomy of Cognitive Domain and dialogicality was organized for the teachers.

There are studies concerning Bloom's Taxonomy in Turkish, however, most of them generally focus on the textbooks, exam questions and other written materials with regard to Cognitive Domain in classes such as Science, Math, Biology and Geography (see Gümüş et al., 2009; Köğçe \& Baki, 2009; Sönmez, Koç, \& Çiftçi, 2013; Eroğlu \& Sarar Kuzu, 2014; Keleş \& Karadeniz, 2015). There is also a very large body of research that provides insight into classroom discourse; however, the present study focuses on the teacher-student interaction by integrating classroom discourse in Bloom's Taxonomy of Cognitive Domain. Keeping in mind that one of the aims of this study is to try to create a change in teachers' pedagogical practices, this study aims to answer the following question:

What is the effect of a training about Bloom's Taxonomy of Cognitive Domain on teachers' pedagogical practices in Turkish language classrooms; that is, are there any differences in teachers' pedagogical practices before and after the training program in terms of Bloom's Taxonomy of Cognitive Domain and dialogicality?

\section{Methodology}

\subsection{Participants}

To determine demographic features of the participants, a personal information form was devised, seeking such information as age, gender and experience. The participants were 8 teachers and their students in Turkish classrooms. Teachers participated in the research voluntarily, without any remuneration. They differed in age, gender and teaching experience. Of the 8 participating teachers, 4 were male and 4 were female, and were still serving 
in the province in which the project was carried out. Table 3 shows the demographic characteristics of these teachers according to age and Table 4 presents characteristics regarding teaching experience.

Concerning age of the participants, their ages ranged from 26 to 56 years old. As illustrated in Table 3, the average age of participants $(n=8)$ was $36.50(S D=9.64)$. Male teachers' $(n=4)$ age was between 31 and $56(M$ $=39.50 ; \mathrm{SD}=11.21)$ and female teachers' $(\mathrm{n}=4)$ age ranged from 26 to $45(\mathrm{M}=33.50 ; \mathrm{SD}=8.18)$.

Years of teaching experience ranged from one year to 30 years. Distribution of the teaching years of the participants was as follows: $50 \%$ were between 1 - 10 years, and the other $50 \%$ were between 10 - 30 years. Teachers $(n=8)$ had an average of 12.75 years of teaching experience $(S D=8.73)$. Male teachers $(n=4)$ had an average of 15.75 years of experience $(S D=9.91)$ while their female $(n=4)$ counterparts had an average of 9.75 years of experience $(\mathrm{SD}=7.45)$.

\subsection{Research Design}

This study is part of a 2-year project supported by the Scientific and Technological Research Council of Turkey (TUBITAK). The experimental research was conducted in secondary schools in different districts of Nevşehir province in central Turkey. The research permission was received from the Ministry of Education, and the schools were randomly selected. The schools generally represented families on the lower level of the socioeconomic status. After the individual school visits of the researchers, 8 teachers from different schools teaching Turkish to $6^{\text {th }}$ and $7^{\text {th }}$ grade classes volunteered to participate in the study.

The research is a single-group based quasi-experimental study which makes use of a pre-test and post-test model. The two treatments included the same content (Bloom's Taxonomy of Cognitive Domain) and had the same duration (80 min) for each class $\left(6^{\text {th }}\right.$ and $7^{\text {th }}$ grade).

Data were collected during the fall and spring semesters of the 2012-2013 school year. In terms of content, all teachers taught the same units specified by the national curriculum. The classes participating in the research used the same Turkish textbook for the appropriate class level. In the single-group design, 8 volunteer teachers were enrolled in a classroom interaction training program. The independent variables of this research consist of the training program, teachers' gender, experience, and class level. The variable "age" is not included in the study because of the correlation with the variable "experience". Age and experience in teachers tend to go together, and teachers tend to gain experience in accordance with their age. The dependent variables in the research are the cognitive levels in class with regard to Bloom's Taxonomy of Cognitive Domain.

Before training in order to prevent any preparation for their lessons, teachers were not given any information on the content of the research. Videotaping took place before and after the training program. Video recording dates were previously scheduled with the teachers and in the pre-training process two 40 -minute lessons of $6^{\text {th }}$ and $7^{\text {th }}$ grade classrooms were video and audio taped during Turkish lessons.

After the first recordings, teachers were given a training covering Bloom's Taxonomy of Cognitive Domain and dialogicality of the classroom discourse. In the post-training process, again two 40 -minute lessons of $6^{\text {th }}$ and

Table 3. Demographic charecteristics of participants $(n=8)$ regarding age.

\begin{tabular}{cccccccc}
\hline & & \multicolumn{5}{c}{ Age of Teachers } \\
Subject & Gender & N & Mean & Median & Standard Deviation & Minimum & Maximum \\
\hline Turkish & M & 4 & 39.500 & 35.500 & 11.210 & 51.000 \\
Turkish & F & 4 & 33.500 & 31.500 & 8.1854 & 26.000 \\
Total & & 8 & 36.500 & 34.000 & 9.636 & 26.000 \\
\hline
\end{tabular}

Table 4. Demographic charecteristics of participants $(n=8)$ regarding experience.

\begin{tabular}{|c|c|c|c|c|c|c|c|}
\hline \multicolumn{8}{|c|}{ Experience of Teachers } \\
\hline Subject & Gender & $\mathrm{N}$ & Mean & Median & Standard Deviation & Minimum & Maximum \\
\hline Turkish & $\mathrm{M}$ & 4 & 15.750 & 13.000 & 9.912 & 7.000 & 30.000 \\
\hline Turkish & $\mathrm{F}$ & 4 & 9.750 & 9.500 & 7.455 & 1.000 & 19.000 \\
\hline Total & & 8 & 12.750 & 12.000 & 8.731 & 1.000 & 30.000 \\
\hline
\end{tabular}


$7^{\text {th }}$ grade classrooms were video and audio-recorded and the effects of this training program have been examined with respect to gender, teacher experience and class level.

\subsection{Recording}

The lessons were recorded using two tripod-mounted digital cameras. Given the inevitability of quiet, unclear, and otherwise difficult-to-transcribe speech in a room with over 20 students, two supplemental digital audio recorders were placed in the opposite corners of each classroom where the video cameras were set up. Due to equipment-related limitations, a few students were outside of the cameras' field of view, but the majority were always visible in each classroom.

One video camera was placed in a front corner and the other camera was placed in a back corner of each classroom. During the lessons, the investigators sat in the back near the camera quietly making field notes, and at the end of each lesson, the equipment was taken down while the teacher and students prepared to leave the classroom.

In order to mitigate the teachers' and students' consciousness of the investigators' and equipment's presence during the recording sessions, observation-only visits were made to each classroom prior to recording.

As it worked out, teachers and students seemed to pay virtually no attention to the investigators or the cameras. As a final check, each teacher was asked, after recording, how conscious s/he had been of the investigators' and the cameras' presence and whether s/he had noticed any differences in the students' behaviors. All teachers indicated that there had been no deviations from the norm.

\subsection{Teacher Training Program}

The training program module was developed in order to develop teachers' awareness of cognitive skills and dialogicality. In order to train teachers on the advanced thinking skills, PowerPoint ${ }^{\circledR}$ slides and handouts were prepared and handed to the targeted teachers in a series of workshops for a week. In the workshops, teachers received input on Bloom's Taxonomy of Cognitive Domain and how to be more dialogical in their classes through PowerPoint ${ }^{\circledR}$ slides, group discussions, peer-led problem-solving sessions and question-and-answer sessions. Teachers were also provided with tasks and activities during the workshops to enhance implementing Bloom's Taxonomy of Cognitive Domain into instruction. Hence, the training program aimed to change teachers' pedagogical practices and discourse behaviors towards a productive classroom discourse. At the end of the workshops, each teacher adapted an existing lesson plan into a productive classroom discourse by providing sentences and as well as questions on the 6 levels of the Cognitive Domain.

After training, all teachers were equipped with the taxonomy and they were expected to put it into practice in their instruction and produce utterances on the higher-cognitive levels during teaching.

\subsection{Transcription and Data Analysis}

The video and audio recordings from the $6^{\text {th }}$ and $7^{\text {th }}$ grade classes of the 8 teachers provided the data for the dependent variables. These recordings have been fully transcribed verbatim into scripts by employing a Conversation Analysis.

Each classroom interaction lasted about 160 minutes (80 min. pre-training and 80 min. post-training). Approximately 42.4 hours of 16 Turkish lessons were transcribed into four columns: Non-verbal, Line, Speaker, and Verbal. The Non-verbal column contains all transcribed visible instances of students' raising hands or other non-verbal discourse. The Line column aligns consecutive reference numbers with each utterance. In the Speaker column was recorded the name (e.g. Teacher, name of the student) of the producer of the utterance on the same line in the adjacent Verbal column. Into the Verbal column were transcribed all audible utterances, in standard orthography. In this column, the speech of teachers was coded as utterances. An utterance is defined as a conversational turn that contains one or more syntactic units and it is usually preceded and followed by a pause (Huttenlocher et al., 2010). As a next step, teachers' utterances were ascribed to the corresponding level of Bloom's Taxonomy of Cognitive Domain using the revised taxonomy.

A reliability measure was applied; both researchers coded the utterances separately and verified their results by comparing the codes for each utterance. Reliability was at least $96 \%$, and conflicts were resolved through comparing codes and discussing differences. Thus, four lessons of each class (two hours of lesson before the 
training program and two hours after) were analyzed. In addition, data obtained before and after the training program, and analyzed according to Bloom's Taxonomy, were compared.

The present study was a single-group pre-test and post-test design and to assess the difference between two baseline measurements Wilcoxon and Wilcoxon Signed Rank tests were applied on the data. Statistical significance for all measures was deemed at $p<0.05$ based on two-independent-sample test. Significant $p$-values $(p<$ 0.05 ) are highlighted in grey in Tables displaying pre- and post-test scores.

\section{Results}

In the present study Wilcoxon and Wilcoxon Signed Rank tests were performed on the pre- and post-test scores separately to examine if mean differences were significant in terms of utterances on the cognitive level, gender, experience, and class level before and after completing the training program.

\subsection{Teachers' and Students' Overall Utterances}

As shown in Table 5, teacher instructional practices after the training program influenced the number of utterances students produced.

The analyses revealed positive relationships between the changes from pre- to post-test on the overall utterances of students. There was a significant increase in students' utterances $(p=0.009<0.05)$ after the training program. No significant changes $(p>0.05)$ have been observed on the total number of utterances of teachers.

\subsection{The Cognitive Levels of Teachers' and Students' Utterances}

In this analysis, the training program and the cognitive levels in class as the dependent variable have been taken into account. Table 6 gives the descriptive statistics of the classroom interaction.

A preliminary inspection of median values showed comparable scores between pre- and post-test. Descriptive comparisons between the median scores of pre- and post-test show an increase in the number of utterances on five levels and a decrease in the number of utterances on the remember level. There was a significant increase in the understand $(p=0.00<0.05)$, apply $(p=0.00<0.05)$, analyze $(p=0.017<0.05)$, evaluate $(p=0.001<0.05)$ and create $(p=0.00<0.05)$ levels and a significant decrease in the remember level $(p=0.021<0.05)$. The decrease in the remember level is a desired result, since this lower-order level does not allow for discussion of problem-solving and mental activities necessary in a productive classroom discourse.

Table 5. Desciptive statistics of teachers’ and students' utterances.

\begin{tabular}{ccccc}
\hline & $\begin{array}{c}\text { Pre-training test score } \\
\text { Median }\end{array}$ & $\begin{array}{c}\text { Post-training test score } \\
\text { Median }\end{array}$ & $\begin{array}{c}p \text { value } \\
\text { (Wilcoxon Test) }\end{array}$ & $\begin{array}{c}\text { TI } \\
\text { (Wilcoxon Signed Rank Test) }\end{array}$ \\
\hline (n) & 8 & 8 & & -6.000 \\
Teacher utterances & 1195.000 & 1267.000 & 0.782 & 49.000 \\
\hline Student utterances & 481.500 & 678.500 & 0.009 & \\
\hline
\end{tabular}

Table 6. Desciptive statistics of teachers' utterances.

\begin{tabular}{ccccc}
\hline & $\begin{array}{c}\text { Pre-training test score } \\
\text { Median }\end{array}$ & $\begin{array}{c}\text { Post-training test score } \\
\text { Median }\end{array}$ & $\begin{array}{c}p \text { value } \\
\text { (Wilcoxon Test) }\end{array}$ & $\begin{array}{c}\text { TI } \\
\text { (Wilcoxon Signed Rank Test) }\end{array}$ \\
\hline (n) & 8 & 8 & 0.021 & -44.000 \\
Remember & 1079.500 & 930.500 & 0.000 & 0.000 \\
Understand & 73.000 & 210.500 & 0.017 & 65.000 \\
Apply & 4.500 & 40.500 & 0.001 & 37.500 \\
Analyze & 0.000 & 14.500 & 6.000 \\
Evaluate & 27.500 & 90.000 & 6000 \\
Create & 0.000 & 13.000 & 6000 \\
\hline
\end{tabular}


The influence of teachers' classroom practice on students' utterances has also been examined. Table 7 presents the descriptive statistics of student utterances on the Cognitive Domain.

According to the results, students revealed a significant change $(p<0.05)$, on five levels, namely understand $(p=0.00<0.05)$, apply $(p=0.001<0.05)$, analyze $(p=0.049<0.05)$, evaluate $(p=0.00<0.05)$ and create $(p$ $=0.001<0.05)$. Students decreased their utterances on remember, the lowest cognitive level, yet this trend did not reach significance $(p>0.05)$.

\subsection{Teacher Experience}

Another purpose of this study was to examine whether years of teaching experience had an effect on teachers' pedagogical practices after training. The analysis of classroom interactions based on teacher experience revealed the following results.

Table 8 shows that both groups of teachers showed significant differences after training. The sign test revealed systematic positive relationships between the changes from pre- to post-test in teachers with less than ten years of teaching experience. These teachers displayed significant differences $(p<0.05)$ on all six levels. Especially on the remember level, there was a dramatic drop $(\mathrm{Mdn}=1147, \mathrm{Mdn}=378)$ and on the evaluate level a drastic increase $(\mathrm{Mdn}=32$, Mdn $=1004)$ on the number of utterances.

Teachers with more than 10 years teaching experience showed also significant differences $(p<0.05)$ from pre- to post-test scores. According to the test results these teachers revealed changes on four levels. The results suggest that although both groups of teachers showed changes on their classroom practices, less experienced teachers were more successful in putting Bloom's Taxonomy into practice.

The study is also interested in students' utterances in order to determine whether teacher experience effects students' production of utterances on higher levels. The information in Table 9 details the changes between pre-

Table 7. Desciptive statistics of students’ utterances.

\begin{tabular}{ccccc}
\hline & $\begin{array}{c}\text { Pre-training test score } \\
\text { Median }\end{array}$ & $\begin{array}{c}\text { Post-training test score } \\
\text { Median }\end{array}$ & $\begin{array}{c}p \text { value } \\
\text { (Wilcoxon Test) }\end{array}$ & $\begin{array}{c}\text { TI } \\
\text { (Wilcoxon Signed Rank Test) }\end{array}$ \\
Remember & 425.000 & 333.000 & 0.130 & -30.000 \\
Understand & 38.000 & 138.000 & 0.000 & 67.000 \\
Apply & 1.000 & 19.500 & 0.001 & 55.000 \\
Analyze & 0.000 & 12.000 & 0.049 & 19.500 \\
Evaluate & 5.500 & 46.000 & 0.000 & 56.000 \\
Create & 0.000 & 26.000 & 0.001 & 33.000 \\
\hline
\end{tabular}

Table 8. Teacher experience: pre-test and post-test assessment of teacher utterances.

\begin{tabular}{|c|c|c|c|c|c|c|c|c|}
\hline & \multicolumn{4}{|c|}{ Teacher Experience < 10} & \multicolumn{4}{|c|}{ Teacher Experience > 10} \\
\hline & \multicolumn{2}{|c|}{ Median } & \multicolumn{2}{|c|}{ Test } & \multicolumn{2}{|c|}{ Median } & \multicolumn{2}{|c|}{ Test } \\
\hline & Pre-test & Post-test & $P^{*}$ & $\mathrm{TI}^{* *}$ & Pre-test & Post-test & $P^{*}$ & $\mathrm{TI}^{* *}$ \\
\hline (n) & 4 & 4 & & & 4 & 4 & & \\
\hline Remember & 1147 & 378 & 0.031 & -10.500 & 1019 & 1128.5 & 0.625 & -5.500 \\
\hline Understand & 61 & 175.5 & 0.031 & 10.500 & 85 & 226 & 0.010 & 24.500 \\
\hline Apply & 1.5 & 70 & 0.031 & 10.500 & 7.5 & 27.5 & 0.023 & 22.000 \\
\hline Analyze & 2.5 & 25.5 & 0.031 & 10.500 & 0 & 2 & 0.383 & 7.000 \\
\hline Evaluate & 32 & 104 & 0.031 & 10.500 & 27.5 & 54 & 0.049 & 19.500 \\
\hline Create & 0 & 22.5 & 0.031 & 10.500 & 0 & 6 & 0.004 & 22.500 \\
\hline
\end{tabular}


Table 9. Teacher experience: pre-test and post-test assessment of students’ utterances.

\begin{tabular}{|c|c|c|c|c|c|c|c|c|}
\hline & \multicolumn{4}{|c|}{ Teacher Experience $<10$} & \multicolumn{4}{|c|}{ Teacher Experience $>10$} \\
\hline & \multicolumn{2}{|c|}{ Median } & \multicolumn{2}{|c|}{ Test } & \multicolumn{2}{|c|}{ Median } & \multicolumn{2}{|c|}{ Test } \\
\hline & Pre-test & Post-test & $P^{*}$ & $\mathrm{Ti}^{* *}$ & Pre-test & Post-test & $P^{*}$ & $\mathrm{Ti}^{* *}$ \\
\hline Remember & 476 & 351.5 & 0.563 & -3.500 & 400 & 308.5 & 0.131 & -15.500 \\
\hline Understand & 23.5 & 204 & 0.031 & 10.500 & 53 & 113 & 0.004 & 26.500 \\
\hline Apply & 0.5 & 64 & 0.031 & 10.500 & 4 & 7.5 & 0.047 & 17.500 \\
\hline Analyze & 1.5 & 53.5 & 0.031 & 10.500 & 0 & 0 & 0.875 & 1.000 \\
\hline Evaluate & 8.5 & 63 & 0.031 & 10.500 & 5 & 34.5 & 0.020 & 19.500 \\
\hline Create & 0 & 37 & 0.031 & 10.500 & 0 & 1 & 0.063 & 7.500 \\
\hline
\end{tabular}

and post-test.

The results in Table 9 illustrate that students of teachers with less than 10 years of experience showed significant scores ( $p<0.05$ ), on five levels (understand, apply, analyze, evaluate and create). However, students of teachers with 10 or more years of experience had significant changes $(p<0.05)$ on three levels understand, apply, and evaluate).

\subsection{Teacher Gender}

An analysis was conducted separately for both female and male teachers to examine if female and male teachers' pedagogical practices changed after completing the training program.

As illustrated in Table 10, results found significant differences between female and male teachers' utterances. The sign test indicated that female teachers revealed systematic positive relationships between the changes from pre- to post-test on five levels. Significant differences $(p<0.05)$ were found on understand, apply, analyze, evaluate and create levels.

As for male teachers, median scores showed statistical significant difference $(p<0.05)$ on three levels, understand, apply, and create. Although there was an increase in the number of utterances on the analyze and evaluate levels, male teachers revealed no significant changes on these levels. No significant differences were found between the pre- to post-test scores of females and the males on the remember level; however a decrease in this lower level was observed in both groups. The results indicate that female teachers produced more utterances on the higher cognitive levels in their classrooms after training. Therefore, it can be said that gender played a significant role in scores.

Table 11 reveals that the students of female teachers had significant scores $(p<0.05)$, on two levels: understand and evaluate. However, students of male teachers showed significant changes $(p<0.05)$ on four levels: understand, apply, evaluate, and create. In general, these results suggest that male teachers' students produced more utterances on the higher levels.

\subsection{Class Level}

Descriptive comparisons in Table 12 between the median scores of pre- and post-test of teachers teaching in the 6th class show an increase in the number of utterances in four levels.

There was a significant increase in the understand ( $p=0.016<0.05)$, apply $(p=0.008<0.05)$, analyze $(p=$ $0.047<0.05)$, and create $(p=0.008<0.05)$ levels. In the 7 th grade, however, significant increase was observed in three levels, namely understand $(p=0.016<0.05)$, evaluate $(p=0.008<0.05)$, and create $(p=0.016<$ 0.05).

According to the results Table 13, students in class 6, revealed a significant change $(p<0.05)$, on four levels: understand, apply, evaluate and create. In class 7 , students had significant difference $(p<0.05)$, on three levels: understand, apply, and evaluate. 
Table 10. Gender: pre-test and post-test assessment of teachers’ utterances.

\begin{tabular}{|c|c|c|c|c|c|c|c|c|}
\hline & \multicolumn{4}{|c|}{ Female Teachers } & \multicolumn{4}{|c|}{ Male Teachers } \\
\hline & \multicolumn{2}{|c|}{ Median } & \multicolumn{2}{|c|}{ Test } & \multicolumn{2}{|c|}{ Median } & \multicolumn{2}{|c|}{ Test } \\
\hline & Pre-test & Post-test & $P^{*}$ & $\mathrm{Ti}^{* *}$ & Pre-test & Post-test & $P^{*}$ & $\mathrm{Ti}^{* * *}$ \\
\hline (n) & 4 & 4 & & & 4 & 4 & & \\
\hline Remember & 1147 & 944.5 & 0.195 & -10.000 & 1019 & 723 & 0.109 & -12.000 \\
\hline Understand & 63 & 235.5 & 0.008 & 18.000 & 85.5 & 175.5 & 0.039 & 15.000 \\
\hline Apply & 4 & 42.5 & 0.016 & 17.000 & 7 & 29 & 0.031 & 15.500 \\
\hline Analyze & 0.5 & 21.5 & 0.016 & 14.000 & 0 & 6 & 0.547 & 4.000 \\
\hline Evaluate & 41 & 103.5 & 0.008 & 18.000 & 14.5 & 56.5 & 0.078 & 13.000 \\
\hline Create & 0 & 12.5 & 0.016 & 14.000 & 0 & 13.5 & 0.008 & 18.000 \\
\hline
\end{tabular}

Table 11. Gender: pre-test and post-test assessment of students' utterances.

\begin{tabular}{|c|c|c|c|c|c|c|c|c|}
\hline & \multicolumn{4}{|c|}{ Female Teachers } & \multicolumn{4}{|c|}{ Male Teachers } \\
\hline & \multicolumn{2}{|c|}{ Median } & \multicolumn{2}{|c|}{ Test } & \multicolumn{2}{|c|}{ Median } & \multicolumn{2}{|c|}{ Test } \\
\hline & Pre-test & Post-test & $P^{*}$ & $\mathrm{Ti}^{* *}$ & Pre-test & Post-test & $P^{*}$ & $\mathrm{Ti}^{* *}$ \\
\hline Remember & 511.5 & 319 & 0.055 & -14.000 & 367.5 & 363 & 1.000 & 0.000 \\
\hline Understand & 25.5 & 167 & 0.016 & 17.000 & 47 & 128.5 & 0.008 & 18.000 \\
\hline Apply & 1 & 19.5 & 0.078 & 11.000 & 1.5 & 34.5 & 0.008 & 18.000 \\
\hline Analyze & 0.5 & 12.5 & 0.063 & 7.500 & 0 & 6.5 & 0.438 & 3.500 \\
\hline Evaluate & 8 & 27 & 0.023 & 16.000 & 5.5 & 54 & 0.016 & 14.000 \\
\hline Create & 0 & 17.5 & 0.063 & 7.500 & 0 & 36 & 0.031 & 10.500 \\
\hline
\end{tabular}

Table 12. Class level: pre-test and post-test assessment of teacher utterances.

\begin{tabular}{|c|c|c|c|c|c|c|c|c|}
\hline & \multicolumn{4}{|c|}{ Class 6} & \multicolumn{4}{|c|}{ Class 7} \\
\hline & \multicolumn{2}{|c|}{ Median } & \multicolumn{2}{|c|}{ Test } & \multicolumn{2}{|c|}{ Median } & \multicolumn{2}{|c|}{ Test } \\
\hline & Pre-test & Post-test & $P^{*}$ & $\mathrm{Ti}^{* *}$ & Pre-test & Post-test & $P^{*}$ & $\mathrm{Ti}^{* *}$ \\
\hline (n) & 8 & 8 & & & 8 & 8 & & \\
\hline Remember & 1181.5 & 915.5 & 0.148 & -11.000 & 1020.5 & 1027.5 & 0.148 & -11.000 \\
\hline Understand & 83 & 174 & 0.016 & 17.000 & 62.5 & 242.5 & 0.016 & 17.000 \\
\hline Apply & 5 & 63.5 & 0.008 & 18.000 & 3.5 & 37.5 & 0.078 & 13.000 \\
\hline Analyze & 0 & 14.5 & 0.047 & 12.000 & 0 & 14.5 & 0.203 & 8.000 \\
\hline Evaluate & 31.5 & 87 & 0.055 & 14.000 & 22 & 90 & 0.008 & 18.000 \\
\hline Create & 0 & 12.5 & 0.008 & 18.000 & 0 & 13.5 & 0.016 & 14.000 \\
\hline
\end{tabular}

Table 13. Class level: pre-test and post-test assessment of students’ utterances.

\begin{tabular}{|c|c|c|c|c|c|c|c|c|}
\hline & \multicolumn{4}{|c|}{ Class 6} & \multicolumn{4}{|c|}{ Class 7} \\
\hline & \multicolumn{2}{|c|}{ Median } & \multicolumn{2}{|c|}{ Test } & \multicolumn{2}{|c|}{ Median } & \multicolumn{2}{|c|}{ Test } \\
\hline & Pre-test & Post-test & $P^{*}$ & $\mathrm{TI}^{* *}$ & Pre-test & Post-test & $P^{*}$ & $\mathrm{TI}^{* *}$ \\
\hline (n) & 8 & 8 & & & 8 & 8 & & \\
\hline Remember & 391 & 333 & 0.641 & -4.000 & 458.5 & 345.5 & 0.109 & -12.000 \\
\hline Understand & 38 & 128.5 & 0.008 & 18.000 & 35 & 172 & 0.016 & 17.000 \\
\hline Apply & 4 & 48.5 & 0.031 & 16.000 & 0 & 19 & 0.031 & 13.000 \\
\hline Analyze & 0 & 7 & 0.188 & 5.500 & 0 & 12 & 0.313 & 4.500 \\
\hline Evaluate & 5.5 & 54 & 0.016 & 14.000 & 6.5 & 34.5 & 0.023 & 16.000 \\
\hline Create & 0 & 18.5 & 0.031 & 10.500 & 0 & 35 & 0.063 & 7.500 \\
\hline
\end{tabular}




\section{Discussion}

This study investigated the extent to which a teacher training program intervention targeting a more dialogical and productive classroom discourse showed positive effects on teachers' pedagogical practices and students' motivation to produce utterances on the higher levels of the Cognitive Domain. In response to our research question, the analysis of teachers' discourse behavior at pre- and post-test of the study indicated that teachers changed their pedagogical practices positively and produced utterances on the higher-cognitive levels after the training program. In this respect, results from the present study revealed two key findings regarding teacher utterances in Turkish classroom. The key result of the study was the prevalence of higher-order instruction strategies after training. After the training program, teachers were scaffolding student understanding by progressing from lower-order to higher-order thinking. This scaffolding helps to support student learning and bridges the gap between student knowledge and conceptual understanding of school subjects. Since the language of schooling expects students to think at higher levels, the more students are introduced with the higher levels of this taxonomy in the classroom discourse, the more successful they will be in their formal education.

Another finding of the study was the big change in the number of utterances produced by students. The total number of student utterances increased. Student talk was low before the training where the utterances were on lower-order thinking. Lower order utterances were generally indicative of teacher-centered instruction in which students were given information and expected to parrot back answers. However, after the training, student talk increased; that is, there was an increase in dialogicality. Thus in classrooms where higher-order utterances were observed, students also engaged more at deeper levels with school subjects. In other words, we present further evidence that productive classroom discourse positively affects students' participation. The results showed that as teachers re-defined their classroom discourse, students' participation and students' utterances on the higher levels increased. Thus, the training program served as an appropriate means to improve student interest in the subject of the class. Teachers' productive discourse scaffolded in a way students' use of utterances on higher cognitive levels.

Together with the training program, this study also examined the independent variables of teachers' gender, experience, and class level. According to the findings from classroom observation, female teachers revealed significant changes in their classroom practices after training. These results suggest that these teachers were more open to the possibilities of change and got engaged with the new process. Although female teachers had higher scores on the cognitive domain, male teachers had more positive effect on student outcomes than female teachers. Male teachers' students elaborated a little more on higher cognitive levels. It seems that male teachers' questions triggered more students' responses on higher levels. Thus, our data seem to support the idea that authentic higher-order questions are actually the ones that elicit higher order utterances from students.

As for experience, pre- and post-test results showed that less experienced teachers scored significantly higher on Cognitive Levels. These results suggest that teachers with less than 10 years of experience had more positive attitudes toward changing classroom practices than did more experienced teachers. Thus, novice teachers might have been more open to changes in teaching practice; however, experienced teachers may have had difficulties changing their classroom practices that have been gained over a long period of time. This experience may have hindered their transfer of new practices into their classrooms.

In terms of class level, both classes revealed positive changes after training; however, no significant differences have been observed between class levels.

In sum, after the successful implementation of a training program focusing on Bloom's Taxonomy of Cognitive Domain and dialogicality, we showed that the increase in the higher cognitive levels in teachers' and students' utterances can be countered to a certain extent by teachers' facilitation of productive classroom discourse. This finding adds to the body of literature that production on higher cognitive levels can be achieved through repeated input on these levels. The results of this study are in accord with previous findings. Brock (1986) found that teachers who had a training about the content and the level of questions they ask in their classrooms asked more open ended questions and that these questions increased the amount of speaking of the students in the classrooms. Nasir \& Abdul Majid Khan (2006) examined teachers' and students' talk over a period of two years and the results displayed that there was an improvement in terms of increase in the share of student talk. Nathan, Kim, \& Grant (2009) compared the classroom discourse before and after teacher participation in professional development activities which aimed to enhance students' classroom participation. They showed that there were changes in classroom discourse structure, in particular, while traditional teacher-led patterns decreased, student-led patterns increased. Turner, Warzon, \& Christensen (2011) investigated patterns of change in teachers’ 
beliefs and practices during a yearlong professional development project. We also observed a similar trend in our study.

From the above discussion, we can conclude that the quality of student learning is closely associated with the quality of classroom discourse. Thus, as teachers, we should attach more importance to spoken discourse during classroom interaction. We should encourage students to generate their own questions and to explore alternative answers. Moreover, authentic questions should be structured to encourage thoughtful answers. In addition, oral tasks should be given greater prominence. In order to achieve this, teachers ought to improve self-teaching skills. If we can improve the quality of classroom discourse, we can certainly raise the quality of student learning (Zhang, 2008). Although classroom discourse is the principal medium of learning in school-Cazden (1988) calls it "the language of learning"- teachers rarely pay attention to how they structure it. Because of their unique role in the classroom, teachers play a key role in moving classroom into dialogic modes (Nystrand, Gamoran, \& Carbonaro, 2001).

\section{Conclusion}

The aim of this research was to develop awareness and improve the quality of classroom education. Using video recordings of classroom interactions, we tried to discover the role of the teacher in facilitating classroom discourse. It is useful for the teachers to become aware of the techniques they use in dialogue. Even good teachers, who probably do these things without being aware that they do so, seem to appreciate gaining this meta-awareness (Mercer, 2002).

Teachers have the unique opportunity to facilitate higher cognitive levels in their students by the discourse patterns they establish in their classrooms and the questions they ask during instruction. If teachers are aware of the effect that their instructional strategies can have on student cognition, they may become more attentive to this aspect of their practice.

Classroom discourse analysis provides teachers with resources to strengthen their instructional techniques, leads student-centered discourse, and facilitates higher levels of cognitive engagement in their students. Classroom discourse studies suggest that acquiring the tools of discourse analysis on classroom interaction raises teachers' awareness and improves mutual understanding between students and teachers. Thus, by rearranging the classroom discourse patterns, teachers attempt to create new classroom interactions that are more productive and enhance more student-centered participation. Our study also shows that with the help of an awareness developing training, teachers can rearrange their classroom discourse patterns that result in more student participation. The quality of the classroom environment is made up of varied components. "As long as we are aware of the vast repertoire of techniques that are at our disposal, it is up to us to choose the specific ones that we will apply, based on the specific needs that arise in our concrete circumstances” (Dornyei, 2007: p. 730).

Although this study contains rich observational data, it is limited in some respects. First of all, this study was limited in that sample size $(n=8)$ was small. Another limitation was that this study looked at Turkish lessons only in the $6^{\text {th }}$ and $7^{\text {th }}$ grades. Future multidisciplinary and as well as longitudinal studies are needed to investigate teachers' classroom patterns and their effects on students' achievement. This study used a single-group based experimental study. Future research could employ an experimental-control group design to examine the effect of the teacher training program on teachers' pedagogical practices and students' motivation to produce utterances on the higher levels of the Cognitive Domain. These studies would be valuable for improving the efficacy of classroom practices and, hence improve student interaction and success in class.

\section{Acknowledgements}

This research is part of a 2-year project (Project number: 112K300) funded by TUBITAK (The Scientific and Technological Research Council of Turkey). We are indebted to TUBITAK for its financial support.

The authors are grateful to the teachers and students who participated in this research, as well as to the principals, parents and district officials who approved it. The authors' sincere thanks go to Tarı Aylan for the transcription of the videotapes.

\section{References}

Alexander, R. (2004). Towards Dialogic Teaching: Rethinking Classroom Talk. Cambridge: Dialogos UK.

Anderson, L. W. \& Krathwohl, D. R. (2001). A Taxonomy for Learning, Teaching and Assessing: A Revision of Bloom's 
Taxonomy of Educational Objectives. New York: Longman.

Behnam, B., \& Pouriran, Y. (2009). Classroom Discourse: Analyzing Teacher/Learner Interactions in Iranian EFL TaskBased Classrooms. Porta Linguarum, 12, 117-132.

Bloom, B. (1956). Taxonomy of Educational Objectives. Book I: Cognitive Domain. New York: David Mckay.

Brock, C. A. (1986). The Effects of Referential Questions on ESL Classroom Discourse. TESOL Quarterly, 20, 77-59. http://dx.doi.org/10.2307/3586388

Carter, R., \& Nunan, D. (2001). Teaching English to Speakers of Other Languages. Cambridge: Cambridge University Press. http://dx.doi.org/10.1017/CBO9780511667206

Cazden, C. (1988). Classroom Discourse: The Language of Teaching and Learning. Porthmouth, NH: Heinemann.

Dornyei, Z. (2007). Creating a Motivating Classroom Environment. In J. Cummins, \& Ch. Davison (Eds.), International Handbook of English Language Teaching (pp. 719-731). New York: Springer Science-Business Media, Inc. http://dx.doi.org/10.1007/978-0-387-46301-8_47

Eroğlu, D., \& Sarar Kuzu, T. (2014), Türkçe Ders Kitaplarındaki Dilbilgisi Kazanımlarının ve Sorularının Yenilenmiş Bloom Taksonomisine Göre Değerlendirilmesi. Başkent University Journal of Education, 1, 72-80.

Faruji, L. F. (2011). Discourse Analysis of Questions in Teacher Talk. Theory and Practice in Language Studies, 1, 18201826. http://dx.doi.org/10.4304/tpls.1.12.1820-1826

Fisher, R. (2006). Thinking Skills. In Arthur, J., Grainger, T. \& Wray, D. (Eds). Learning to Teach in Primary School (pp. 226-238). Routledge: Falmer.

Forehand, M. (2005). Bloom's Taxonomy: Original and Revised. In M. Orey (Ed.), Emerging Perspectives on Learning, Teaching, and Technology (E-Book). https://textbookequity.org/Textbooks/Orey_Emergin_Perspectives_Learning.pdf

Grugeon, E., \& Hubbard, P. (2006). Learning through Dialogue. In J. Arthur, T. Grainger, \& D. Wray (Eds.), Learning to Teach in Primary School (pp. 239-250). Routledge: Falmer.

Gümüş, I., Ermurat, D.G., Kaya, Y., Kırıcı, M., \& Kurt, M. (2009). Analysis for High School Biology Exam Questions According to Their Cognitive Development Levels. Erzincan Eğitim Fakültesi Dergisi Cilt-Sayl, 11-12, 151-162.

Hicks, D. (1995). Discourse, Learning, and Teaching. Review of Research in Education, 21, 49-95. http://dx.doi.org/10.2307/1167279

Hsiao, C. (2005). Teacher-Student Communication Patterns in an English Language Class: Examination of Classroom Discourse. Academic Journal of Kang Ning, 7, 285-304.

Huttenlocher, J., Waterfall, H., Vasilyeva, M., Vevea, J., \& Hedges, L. V. (2010). Sources of Variability in Children’s Language Growth. Cognitive Psychology, 61, 343-365. http://dx.doi.org/10.1016/j.cogpsych.2010.08.002

Keleş, T., \& Karadeniz, M.H. (2015). 2006-2012 Yılları Arasında Yapılan ÖSS, YGS ve LYS Matematik ve Geometri Sorularının Bloom Taksonomisinin Bilişsel Süreç Boyutuna Göre İncelenmesil (An Analysis of Mathematics and Geometry Questions in OSS, YGS and LYS According to the Revised Bloom Taxonomy Between 2006-2012 Years). Turkish Journal of Computer and Mathematics Education, 6, 532-552. http://dx.doi.org/10.16949/turcomat.48130

Köğçe, D., \& Baki, A. (2009). Matematik Öğretmenlerinin Yazılı Sınav Soruları ile ÖSS Sınavlarında Sorulan Matematik Sorularının Bloom Taksonomisine Göre Karşılaştırılması, Pamukkale Üniversitesi, Eğitim Fakültesi Dergisi, 26, 70-80.

Krathwohl, D. R. (2002). A Revision of Bloom's Taxonomy: An Overview. Theory into Practice, 41, 212-218. http://dx.doi.org/10.1207/s15430421tip4104 2

Lefstein, A., \& Snell, J. (2011). Classroom Discourse: The Promise and Complexity of Dialogic Practice. In S. Ellis, E. McCartney, \& Bourne, J. (Eds.), Applied Linguistics and Primary School Teaching (pp. 165-185). Cambridge: Cambridge University Press. http://dx.doi.org/10.1017/CBO9780511921605.018

Mercer, N. (2000). Words and Minds: How We Use Language to Think Together. London: Routledge. http://dx.doi.org/10.4324/9780203464984

Mercer, N. (2002). Developing Dialogues. In G. Wells, \& G. Claxton (Eds.) Learning for Life in the C21st: Sociocultural Perspectives on the Future of Education. Oxford: Blackwell. http://dx.doi.org/10.1002/9780470753545.ch11

Nasir, M., \& Abdul Majid Khan, R. (2006). Constructivist Classroom: Elements of Class Discourse as Measure of Constructivist Practice. Bulletin of Education \& Research, 28, 23-34.

Nathan, M. J., Kim, S., \& Grant, T. S. (2009). Instituting Change in Classroom Discourse Structure: Human and Computer Based Motif Analysis. (WCER Working Paper No. 2009-1). Madison: Wisconsin Center for Education Research, University of Wisconsin. http://www.wcer.wisc.edu/publications/workingPapers/papers.php

Nunan, D. (1993). Introducing Discourse Analysis. London: Penguin English.

Nystrand, M., Gamoran, A., \& Carbonaro, W. (2001). On the Ecology of Classroom Instruction: The Case of Writing in High School English and Social Studies. In P. Tynjälä, L. Mason, \& K. Londa (Eds.), Writing as a Learning Tool (pp. 57- 
81). Dordrecht: Kluwer Academic Publishers. http://dx.doi.org/10.1007/978-94-010-0740-5_5

Smith, C. (2005). Developing Children's Oral Skills at Key Stage 2. In E. Grugeon, L. Dawes, C. Smith, \& L. Hubbard (Eds.), Teaching Speaking and Listening in the Primary School (3rd ed., pp. 84-102). London: David Fulton Publishers.

Sönmez, Ö. F., Koç, H. \& Çiftçi, T. (2013). ÖSS, YGS ve LYS Sınavlarındaki Coğrafya Sorularının Bloom Taksonomisi Bilişsel Alan Düzeyi Açısından Analizi. Karadeniz Araştırmaları, 36, 257-275.

Turner, J. C., Warzon, K. B., \& Christensen, A. (2011). Motivating Mathematics Learning: Changes in Teachers’ Practices and Beliefs during a Nine-Month Collaboration. American Educational Research Journal, 48, 718-762. http://dx.doi.org/10.3102/0002831210385103

Vygotsky, L. S. (1978). Mind in Society: The Development of Higher Psychological Processes. Cambridge, Mass.: Harvard University Press.

Wells, G. (1999) Dialogic Inquiry: Towards a Sociocultural Practice and Theory of Education. Cambridge: Cambridge University Press. http://dx.doi.org/10.1017/CBO9780511605895

Xu, X.-H. (2010). Analysis of Teacher Talk on the Basis of Relevance Theory. Canadian Social Science, 6, 45-50.

Zhang, Y. (2008). Classroom Discourse and Student Learning. Asian Social Science, 4, 80-83. 